\title{
Red Propolis Antifungal Action on Species of Candida of the Oral Cavity
}

Anne Milane Formiga Bezerra1, Maria do Carmo Andrade Duarte de Farias², Kévia Katiúcia Santos Bezerra², Francisco Geyson Fontenele Albuquerque ${ }^{3}$, Antônio Fernandes Filho², Geofabio Sucupira Casimiro², Elicarlos Marques Nunes ${ }^{4}$, Edivânia Maria Leite da Silva ${ }^{5}$, Wilma Kátia Trigueiro Bezerra', Palloma Batista de Almeida1, Tereza Lourença Matias de Araújo1, Kennia Sibelly Marques de Abrantes ${ }^{2,6}$, Luiz Carlos de Abreu ${ }^{6}$, Patrício Borges Maracajá7, Alfredina dos Santos Araújo ${ }^{7}$, Rosilene Agra da Silva ${ }^{7}$

\section{Abstract}

Introduction: Propolis is a substance that has aroused the interest of many researchers because of its numerous therapeutic properties, antibacterial and antifungal.

Objectives: Identifying the species of Candida and evaluate the antifungal effect of red propolis yeast oral cavity.

Method: This is a clinical in vitro study with saliva samples collected from 152 patients treated at the dental office of the Family Health Strategy in the city of São Bento-PB. The identification of Candida species was made through the Chrom Ágar Candida. The antifungal activity of the propolis extract was analyzed in four different concentrations: $100 \%, 75 \%, 50 \%$ and $25 \%$, through the agar diffusion test.

Results: The most prevalent species was C. albicans; antifungal action as to the concentration of $25 \%$ of the propolis extract was that apparently demonstrated greater efficacy, compared to the highest concentration.

Conclusion: The inhibitory effect of propolis against Candida may have been influenced by the concentration of alcohol present in the extract. To test this hypothesis suggests that search is performed with extracts of propolis and at the same time with the alcohol, in both concentrations and different environmental conditions. This study offers subsidies for other professionals employ different methodologies and propolis concentrations with other substances in order to test the antimicrobial action of these.
1 Nurse in a Mobile Emergency Service, MSU, Sousa, PB, Brazil.

2 Academic Unit of Life Sciences, Teacher training center, Federal University of Campina Grande.

3 Student of Medicine, Academic Unit of Life Sciences, Federal University of Campina Grande.

4 Faculties Integrated of Patos, PB, Brazil.

5 MSB Visual Communications Ltda - Design and Visual Communication, João Pessoa, PB, Brazil.

6 Scientific Writing Laboratories, Faculty of Medicine of ABC, Santo Andre, SP, Brazil.

7 Federal University of Campina Grande. Graduate-degree in Agroindustrial Systems, Pombal, PB, Brazil.

\section{Contact information:}

Maria do Carmo Andrade Duarte de Farias.

Academic Unit of Life Sciences, Teacher training center, Federal University of Campina Grande.

Address: Federal University of Campina Grande. Rua Sérgio Moreira de Figueiredo, sn Bairro Casas Populares, Cajazeiras, PB CEP 58900-000.

” carmo.andrade@ufcg.edu.br

Keywords

Propolis; Candida; Oral cavity;

Products with antimicrobial action. 


\section{Introduction}

Oral Candidiasis is an infection caused by Candida yeasts, saprobes microorganisms that, dependent on predisposing factors, become pathogenic [1]. This type of infection is most common in immunocompromised individuals and presented increasing incidence in recent years [2]. C. albicans is the most frequently identified species and therefore responsible for this type of infection. However, infections caused by other species of the genus are becoming more frequent, being cited approximately 150 species, most isolated from the oral cavity [3].

C. albicans is considered the main opportunistic pathogenic yeast to be the most frequently isolated species in humans. However, in recent decades there has been a significant increase of other species. The main of medical concern are C. parapsilosis, C. tropicalis, C. krusei, C. guilliermondii, C. glabrata, C. lusitaniae. C. kefyr, C. famata, C. dubliniensis [4-5].

The species identification is important, fungal infections caused by Candida, since the pathogenicity and sensitivity to a particular antifungal vary between different species [6].

The widespread use of azole antifungal for the treatment of oral candidiasis appears to be a major factor in the increased frequency of Candida non-albicans species, especially those naturally more resistant to this class of antifungals such as C. glabrata and C. krusei [7]. Recent studies indicate that there is an increase in resistance of Candida species to antifungal drugs available on the market [8].

A drawback of the azole is that they are depending on the concentration, fungistatic, not fungicidal, which may contribute to the development of resistance in clinical isolates [9]. Resistance to azole antifungals may result from target sites of mutation or increased gene expression of proteins responsible for the transport of antifungal to the outside, or even the combination of these two mechanisms, which have been observed in isolated C. albicans [10].
This fact has stimulated the search for increasingly new antifungal agents from natural sources and propolis emerges as an important coupled to present a wide diversity of active compounds, many still unknown, with reported biological properties, which may enable the discovery of new bioactive molecules to processes treatments oral disease.

The range of biological activities of propolis is higher in tropical areas of the world, reflecting the plant diversity of these regions [11]. Because of the diversity of the flora, propolises from Brazil were grouped into 12 different groups, according to the chemical composition and biological activities. Currently, a new variety of propolis, originating from the mangrove area in the state of Alagoas (Brazil), had its botanical origin identified as Dalbergia ecastophyllum, a kind of legume [12]. This propolis, called "red propolis", because of its intense red coloration, was scored as the 13th type of brazilian propolis and have shown various biological activities in vitro assays [13].

Trying to understand the action of propolis, this research was carried out aiming to identify Candida species in the oral cavity and evaluate in vitro antifungal activity of the red propolis extract the yeast of the oral cavity.

\section{Material and Method}

The research is a clinical study in vitro with saliva samples collected from 152 patients treated at the dental office of the Family Health Strategy Ivan Olimpo Segundo, in the municipality of São Bentinho-PB, with Oral Swab Sterile aid. The handling of clinical samples was performed at the Laboratory of Vocational Technology Center (VTC) of the Federal University of Campina Grande, PB, Campus Pombal-PB. Patients consented to participate in the survey after they had read, understood and signed two copies of a Free and Clear Informed Consent. In compliance with Resolution 466/12, the research was approved by the Research Ethics Committee of 
the Federal University of Campina Grande, CAAE 37184414.5.0000.5575 protocol. Made the collection of oral secretions, identification of the fungus in culture was carried out from the sow Agar Potato Dextrose. The plates were incubated at $37^{\circ} \mathrm{C}$ for five days. After this period, the growth characteristics of Candida colonies were checked. The identification (Figure 1) occurred by studying the macroscopic aspects, micro morphological and biochemical in Chrom Ágar Candida ${ }^{\circledR}$. The medium used indicates green colonies, for $C$. albicans; rugose rose, for $C$. krusei; metallic blue, for C. tropicalis; and white to violet, for other species [10, 14-15].

The red propolis samples of Apis mellifera bees arising from the Dalbergia ecastophyllum (Bugiu-ofTail), whose extract was held to $30 \%$ ethyl alcohol PA were acquired in Apiary EDIMEL- João Pessoa - Paraiba.

The antifungal activity of the propolis extract was analyzed in four different concentrations: 100\%, 75\%, 50\% and 25\%, determined by Agar diffusion test in which the samples of Candida were identified and seeded Agar Potato Dextrose and incubated at $35^{\circ} \mathrm{C} / 48 \mathrm{~h}$.

Figure 1: Candida species identification in samples of saliva, through the Chrom Agar Candida ${ }^{\circledR}$.
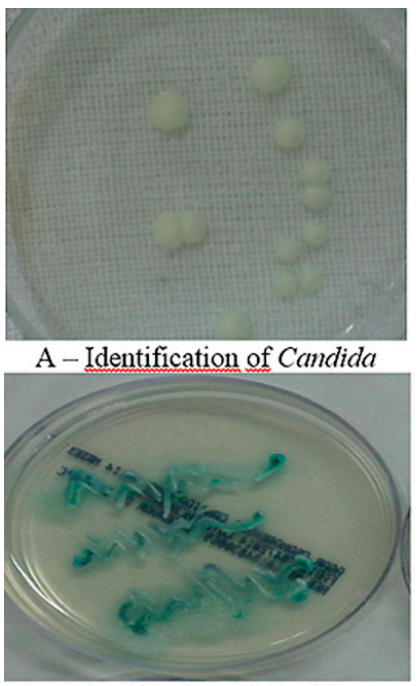

C - Identification of C. albicans
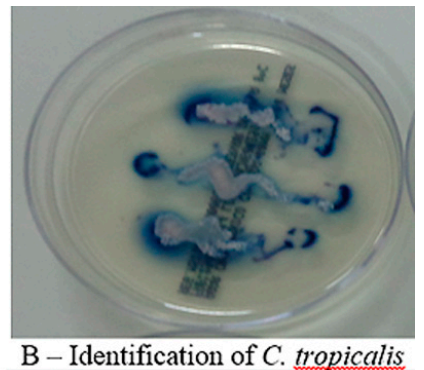

Source: Survey data. São Bentinho-PB, 2014
Then, paper disks were soaked with $10 \mu \mathrm{L}$ used extract concentrations in the three and deposited on the surface of the agar. The plates were incubated at $37^{\circ} \mathrm{C} / 48 \mathrm{~h}$. After the measurement was performed halos of inhibition of Candida growth (Figure 2). From the results, it was considered active product against the species of the microorganisms under study which produced halos that above $10 \mathrm{~mm}$ in diameter [16].

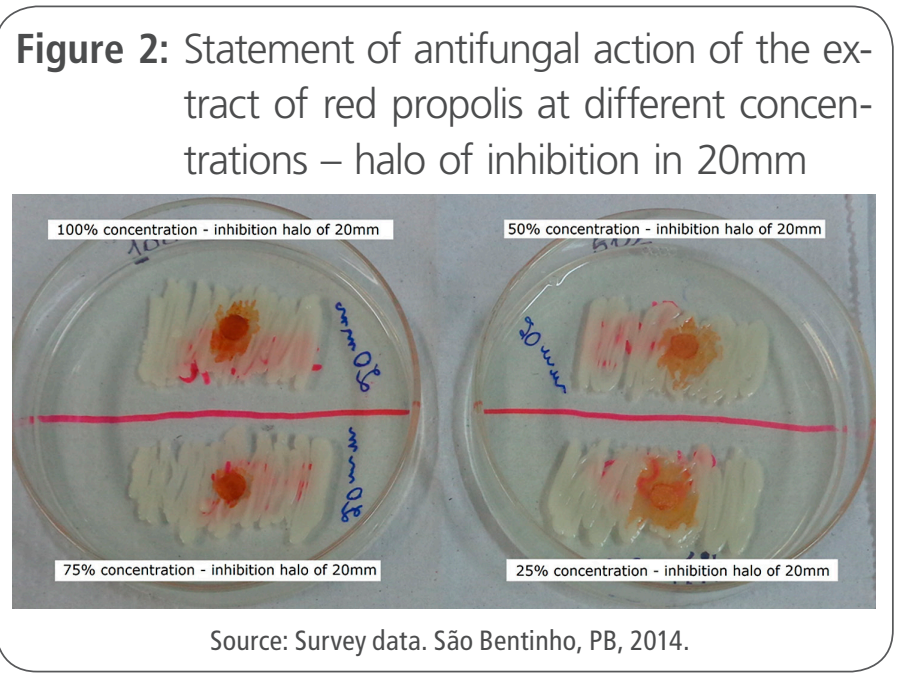

\section{Results}

\section{Saliva collection}

The result of the salivary culture of 152 participants showed that $27.0 \%(n=41)$ were positive for some species of Candida. The data in Table 1 demonstrate the Candida species identified in samples whose culture was positive. Those findings, the species Candida albicans prevailed with $68.3 \%(n=28)$, followed of other unidentified species from the culture medium with $14.6 \%(n=6)$.

It was noticed by the findings that half $(n=14)$ species of $C$. albicans was samples from individuals with clinically healthy mouth, whose reason has been demand service restoration $(n=12)$ and the dental review ( $n=2$ ) (data not shown in tables).

The distribution of Candida species according to the gender of the participants, it is clear that in all 
Table 1. Species of Candida identified in samples of salivary culture $(n=41)$.

\begin{tabular}{|l|c|c|}
\hline \multicolumn{1}{|c|}{ Species of Candida } & $\mathbf{n}$ & $\%$ \\
\hline C. albicans & 28 & 68.3 \\
\hline C. krusei & 4 & 9.8 \\
\hline C. tropicalis & 3 & 7.3 \\
\hline Other species & 6 & 14.6 \\
\hline
\end{tabular}

Source: Survey data. São Bentinho-PB, 2014.

species was greater prevalence in women; the exception of $C$. krusei because the percentages were the same for men and women (Table 2).

Table 2. Distribution of Candida species identified in salivary culture according to the gender of the respondents $(n=41)$.

\begin{tabular}{|l|c|c|c|c|}
\multirow{2}{*}{ Species of Candida } & \multicolumn{4}{|c|}{ Gender } \\
\cline { 2 - 5 } & \multicolumn{2}{|c|}{ Woman } & \multicolumn{3}{|c|}{ Man } \\
\hline C. albicans $(\mathrm{n}=28)$ & 23 & 82.1 & 5 & 17.9 \\
\hline C. Krusei $(\mathrm{n}=4)$ & 2 & 50.0 & 2 & 50.0 \\
\hline C. tropicalis $(\mathrm{n}=3)$ & 3 & 100.0 & 0 & 0.0 \\
\hline Other species $(\mathrm{n}=6)$ & 5 & 83.3 & 1 & 16.7 \\
\hline
\end{tabular}

Source: Survey data. São Bentinho-PB, 2014.

In addition to the evidence found on the higher prevalence of Candida in women, it was noticed the same fact in participants whose ages ranged from 7 to 30 years, except for C. krusei, for all cases met the participants of full age (Table 3 ).

Interestingly, in this study, cases of Candida prevailed in younger patients (Table 3 ) and only 9.7\%

Table 3. Distribution of Candida species identified in salivary culture according to the age of the respondents $(n=41)$.

\begin{tabular}{|l|c|c|c|c|}
\multirow{2}{*}{ Species of Candida } & \multicolumn{4}{|c|}{ Age (years) } \\
\cline { 2 - 5 } & \multicolumn{2}{|c|}{7 to 30} & \multicolumn{2}{|c|}{31 to 70} \\
\hline C. albicans $(n=28)$ & $n$ & $\%$ & $n$ & $\%$ \\
\hline C. krusei $(n=4)$ & 0 & 71.4 & 8 & 28.6 \\
\hline C. tropicalis $(n=3)$ & 3 & 100.0 & 0 & 0.0 \\
\hline Other species $(n=6)$ & 5 & 83.3 & 1 & 16.7 \\
\hline
\end{tabular}

Source: Survey data. São Bentinho-PB, 2014
(4/41) of cases of Candida wore partial denture, of which 2 were of C. albicans and 2 species, C. krusei (data not shown in tables).

\section{Antifungal action of the red propolis extract}

When testing the antifungal effect of propolis on 41 samples with Candida species identified, it was noted that in $61 \%(n=25)$ the result was positive. Analyzing this positivity, it was realized that, except for "other species identified" positive antifungal action prevailed in the other, since the percentages were $64.3 \%(n=18)$ in C. albicans, $75 \%(n=3)$ in C. krusei, 66.7\% ( $n=2)$ in C. tropicalis (Table 4).

Table 4. Distribution of Candida species identified in salivary culture as antifungal action of red propolis extract $(n=25)$.

\begin{tabular}{|l|c|c|}
\hline \multirow{2}{*}{ Species of Candida } & \multicolumn{2}{|c|}{ Positive } \\
\cline { 2 - 3 } C. albicans $(\mathrm{n}=28)$ & $\mathbf{n}$ & $\%$ \\
\hline C. krusei $(\mathrm{n}=4)$ & 18 & 64.3 \\
\hline C. tropicalis $(\mathrm{n}=3)$ & 3 & 75.0 \\
\hline Other species $(\mathrm{n}=6)$ & 2 & 66.7 \\
\hline
\end{tabular}

Source: Survey data. São Bentinho-PB, 2014.

In the above mentioned concentrations of the propolis extract, added to samples containing Candida species, it was possible to identify variations from 0 to $60 \mathrm{~mm}$ in the inhibition halos. Table 5 reveals that the average of these halos increased as the concentrations were reduced; $0 \mathrm{~mm}$ the percentage reduced, as has reduced the concentration of extract; the positive $60 \mathrm{~mm}$ was only observed at concentrations of $75 \%$ and $25 \%$.

For greater understanding of antifungal action of red propolis extract were excluded lower results than or equal to $10 \mathrm{~mm}$, at all concentrations, as shown in Chart 1.

The Chart 1 indicate that by reducing red propolis extract concentrations were added the cases of positivity antifungal action, from $n=13$, concentration $100 \%$, for $n=20,25 \%$ in concentration. This association was not observed in the mean positive 
Table 5. Results of the halos of inhibition of antifungal action of the red propolis extract in the concentrations to $100 \%, 75 \%, 50 \%$ and $25 \%$. $(n=25)$.

\begin{tabular}{l|c|c|c|c}
\hline \multirow{2}{*}{ Results $(\mathbf{m m})$} & \multicolumn{4}{c}{ Concentrations of the red propolis extract } \\
\hline Average (SD) & $100 \%$ & $75 \%$ & $50 \%$ & $25 \%$ \\
\hline Minimum-Maximum & $18.80 \pm 17.64$ & $22.00 \pm 18.26$ & $24.00 \pm 17.32$ & $26.40 \pm 18.00$ \\
\hline $0 \mathrm{~mm}$ & $0-50$ & $0-60$ & $0-50$ & $0-60$ \\
$10 \mathrm{~mm}$ & $32 \%(n=8)$ & $24 \%(n=6)$ & $20 \%(n=5)$ & $12 \%(n=3)$ \\
\hline $20 \mathrm{~mm}$ & $16 \%(n=4)$ & $12 \%(n=3)$ & $12 \%(n=3)$ & $8 \%(n=2)$ \\
\hline $30 \mathrm{~mm}$ & $16 \%(n=4)$ & $28 \%(n=7)$ & $20 \%(n=5)$ & $40 \%(n=10)$ \\
\hline $40 \mathrm{~mm}$ & $16 \%(n=4)$ & $12 \%(n=3)$ & $20 \%(n=5)$ & $16 \%(n=4)$ \\
\hline $50 \mathrm{~mm}$ & $8 \%(n=2)$ & $8 \%(n=2)$ & $12 \%(n=3)$ & $4 \%(n=1)$ \\
\hline $60 \mathrm{~mm}$ & $12 \%(n=3)$ & $12 \%(n=3)$ & $16 \%(n=4)$ & $8 \%(n=2)$ \\
\hline & - & $4 \%(n=1)$ & - & $12 \%(n=3)$ \\
\hline
\end{tabular}

Source: Survey data. São Bentinho-PB, 2014.

Chart 1: Distribution of antifungal action in $\mathrm{mm}$ of red propolis extract at concentrations to $100 \%, 75 \%, 50 \%$ and $25 \%$.

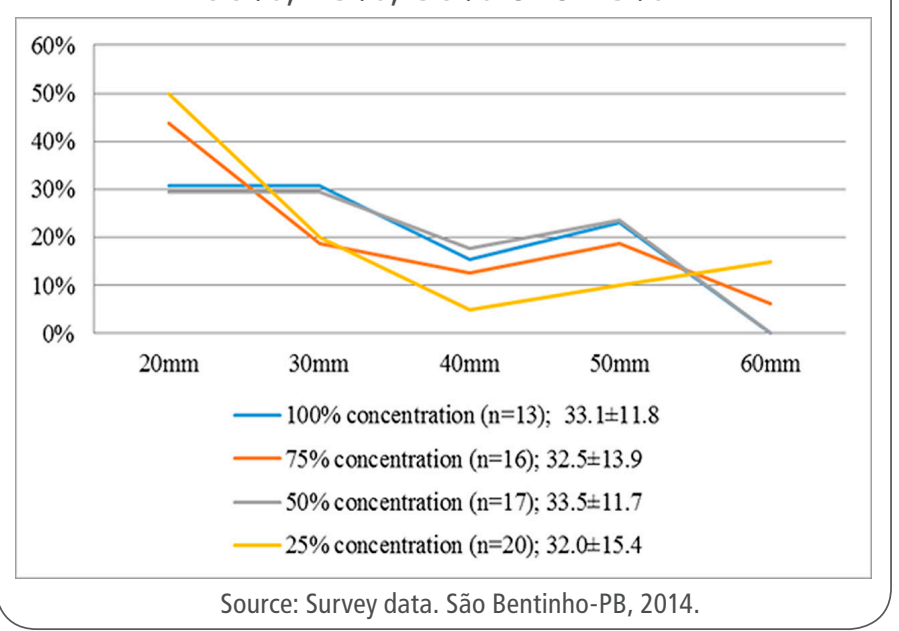

aspects of mergers, because there was almost equivalent concentrations at $100 \%$ and $50 \%$; and at concentrations of $75 \%$ and $25 \%$.

However, the graphical representation, this trend was not observed in millimetric terms, since there was an increasing linearity in the positivity of antifungal action, as reduced or increased the concentration of propolis extract.

What was observed, on time, it was the highest percentage of $50 \mathrm{~mm}$ of positivity found in $23.5 \%$ $(n=4)$ for the concentration of the extract by $50 \%$; and comparing all concentrations, the highest per- centage of positivity was $20 \mathrm{~mm}$, equal to $50 \%$ (n $=10$ ), referring to the concentration of $25 \%$ of the extract.

\section{Discussions}

The high prevalence of C. albicans, found in this study corroborates the claim that this is the main agent of candidiasis, and this species is $60 \%$ of isolates from clinical samples as it is part of human macrobiota [5].

In this sense, scholars [17] found in $82.8 \%$ of patients studied in C. albicans species. Meanwhile, in another study [18] obtained $62.66 \%$ and $66,4 \%$, respectively, of the same species.

About this prevalence, this fact can be justified due to the ability of the $C$. albicans has to produce secreting enzymes such as phospholipase, which plays an important role in the pathogenesis of these yeast [19-21]. The activity of extracellular phospholipase facilitate the capacity of these yeasts to invade host cells and/or processed to remove antigens from the surface of these cells [22].

Contrary to this research, researchers [23] found in the saliva of all samples studied, a frequency of $48 \%(24 / 50)$ of C. albicans. That was the most prevalent species in all groups investigated, healthy 
or not. However, they identified $47.7 \%$ of the C. albicans species in patients without oral problems.

Regarding gender, research [24] has shown that, in the sample of 51 women evaluated, 13 (25.5\%) had a clinical diagnosis of Vulvovaginal Candidiasis (VVC), and of these, five (9.8\%) showed yeasts of the genus Candida were also in the oral cavity. The authors observed that from the 15 women without clinical of VVC, 11 (73.3\%) showed the yeast in the oral cavity, four (26.7\%) in the vaginal mucosa and three (20\%) in both sites. In addition, they assessed that although there was no statistically significant correlation between species and sites; women had oral and vaginal candidiasis due to different etiologic agents. Therefore, they should always be advised to maintain good hygiene habits.

The frequency of Candida sp. in oral mucosal lesions was identified variable way, by researchers who investigated 832 biopsies of the oral mucosa, of which $27.2 \%$ were positive; they confirmed the increased presence of Candida in the lesions, being more frequent in males [25].

With regard to age, the C. albicans was found in the oral cavity from $3 \%$ to $48 \%$ of all adults and $45 \%$ to $65 \%$ of healthy individuals [26]; contradicting the findings in research whose sample consisted of $98.4 \%$ adult participants, of which $16.9 \%$ reported some pathological episode of oral candidiasis [27].

The relation age and C. albicans is reported in a study whose incidence of yeast increased with age, and its presence in the oral cavity, has reached $60 \%$ of the edentulous patients over 60 years, who had no signs of injury in the oral mucosa [28].

In recent decades there has been an increasing use of the propolis extracts to assist in the treatment of oral infections, due to their antimicrobial properties.

Different methods in vitro are used for analysis of propolis extracts against species of Candida [29]. The antifungal activity of propolis in different species of Candida was demonstrated in researches
[30], and were also described the effects of the time of year in the activity of Brazilian propolis in C. albicans and C. tropicalis [31].

The results of this study did not reveal clarity regarding the antifungal effect of red propolis, since the trend of positivity of this action was not growing by increasing or decreasing the concentration of propolis extract. What was observed was that concentration at which 50\% was obtained larger inhibition zone, with an average of $33.5 \mathrm{~mm}( \pm 11.7)$, then the concentration to $25 \%$, average $32.0 \mathrm{~mm}$ $( \pm 15.4)$. On the other hand, analyzing the average and standard deviation of each concentration, it suggested greater efficacy of antifungal activity was the concentration at $25 \%$. These facts raise the possibility that the antifungal action, found in this study, is related to the higher concentration of alcohol added to propolis.

Therefore, studies must be intensified, since research proves natural variations in the chemical composition of propolis extract. In such research, propolis showed excellent antifungal activity, and the concentration was able to inhibit all the yeasts in $5 \times 10-2 \mathrm{mg} / \mathrm{ml}$ of flavonoids and $2 \times 10-2 \mathrm{mg} / \mathrm{ml}$ of flavonoids, stimulating cell death, ie $25 \%$ and $50 \%$ [32].

In a recent study, the activity of propolis produced in Tocantins, in general, showed greater antifungal activity for $C$. tropicalis, with an average of $12 \mathrm{~mm}$ of inhibition zone diameter and especially the Palmas-CPI propolis (16 mm). It showed a slightly lower activity for $C$. albicans, average diameter of $11 \mathrm{~mm}$, with the best result corresponding to propolis from Nova Olinda-CPI (15mm) [33].

The in vitro effect of alcoholic propolis extract (APE) produced in different regions, on five species of micro-organisms (Staphylococcus aureus, Escherichia coli, Enterococcus sp., Pseudomonas aeruginosa and Candida albicans) was evaluated. The researchers observed that was a statistical difference in the Minimum Inhibitory Concentration (MIC) between the three extracts and that the Gram-positive 
microorganisms and yeasts were those with greater sensitivity [34]. However, other scholars argue that the antimicrobial activity of propolis should be attributed to all its components, as identified that the APE action obtained from different locations was similar [35].

In this sense, the methods employed in the studies that evaluated the antimicrobial activity of propolis extract were very different, making it difficult to compare results. However, it is recognized that gram-positive bacteria are more susceptible to the action of various propolis extracts than the Gramnegative bacteria [36].

Despite the antibacterial action of propolis being well established in the literature, little is said of its antimicrobial action on yeasts. Thus, it was found that glycolic extract of propolis was effective on $C$. albicans, even in more diluted concentrations [37]. Researchers evaluated the in vitro effect of alcoholic propolis extract on 80 species of Candida yeasts and found that all strains were sensitive to this extract [38]. Comparing these two studies, it should be emphasized that in the first [37] it was used glycolic propolis extract, and not the alcoholic, used in most studies.

Using ethanol propolis extracts, the growth of C. albicans and S. aureus was not inhibited, demonstrating that the bioactive compounds of the samples did not have antibiotic activity [39]. By the results probably the propolis acted more as a physical barrier, than as an own biological protection for the micro-organisms tested [40].

Recently, researchers [41] obtained excellent results for C. albicans, especially for acetanolic fraction, wherein the minimum inhibitory concentration (MIC) is compared to the values found for the analyzed Gram-positive bacteria; contrary to the results found by other researchers [42], in which propolis extracts did not inhibit the growth of pathogens tested. The larger inhibition zone was of $4 \mathrm{~mm}$ at $20 \%$ and $30 \%$ concentrations, being not sufficient to reveal antibacterial activity.
Also in this sense, few studies have proposed the combination of propolis extract with antimicrobial agents, to decrease the clinical dose of certain antibiotics, as well as reducing the incidence of side effects and at the same time, enhance the antibiotical therapy [43-44].

Facing the exposed, the researches, overall, reveal more the antibacterial action of propolis than the antifungal.

\section{Conclusion}

Regarding the antifungal activity of red propolis, it was observed that its inhibitory process against Candida may have been influenced by the concentration of alcohol present in the extract, as there was evidence that the lowest concentration of propolis extract had higher antifungal record, compared to the higher concentration.

To test this hypothesis, it is suggested that research is performed with extracts of propolis and at the same time with alcohol, in both different concentrations and environmental conditions. So, this study offers subsidies for other professionals assess this fact, performing works with extracts prepared with different substances and concentrations, in order to test the antimicrobial action of these.

\section{References}

1. Ramos INC, Vasconcelos LCS, Lima MGGC, Figueiredo RLQ. Candidose bucal em pacientes HIV- positivos. JBC j bras odontol Clin. 1999 ;3(13): 59-61.

2. Aleva NA, Birman EG, Afonso Júnior W, Chavasco JK, Paula $C R$, Ribeiro $A$, et al. Erythematous candidosis in patients with complete dentures and HIV+/AIDS. Mycoses. 2007; 50(5): 40711. DOI: 10.1111/j.1439-0507.2007.01390.x

3. Alves DLN. Candida spp. e prótese dentária removível [Monografia]. Fernando Pessoa: Faculdade de Ciências da Saúde; 2009

4. Colombo AL, Guimaraes T. Epidemiologia das infecções hematogênicas por Candida spp. Rev Soc Bras Med Trop. 2003; 36 (5): 599-607. DOI: 10.1590/S0037-86822003000500010

5. Barbedo LS, Sgarbi DBG. Candidíase. DST J Bras Doenças Sex Transm. 2010; 22(1): 22-38. Disponível em: <http://www.dst. uff.br/revista22-1-2010/4-\%20Candidiase.pdf> 
6. Mímica LMJ, Ueda SMY, Martino MDV, Navarini A, Martini IJ. Diagnóstico de infecção por Candida: avaliação de testes de identificação de espécies e caracterização do perfil de suscetibilidade. J Bras Patol Med Lab. 2009; 45 (1): 17-23 DOI: 10.1590/S1676-24442009000100005

7. Dronda F, Alonso-Sanz M, Laguna F, Chaves F, MartínezSuárez JV, Rodríguez-Tudela JL, et al. E. Mixed oropharyngeal candidiasis due to Candida albicans and non-albicans Candida strains in HIV- infected patients. Eur J Clin Microbiol Infect Dis. 1996 Jun; 15 (6): 446- 52. DOI: 10.1007/BF01691310

8. Begnami AF, Duarte MCT, Furletti $V$, Rehder VLG. Antimicrobial potential of Coriandrum sativum L. against different Candida species in vitro. Food Chemistry. 2010 Jan; 118 (1): 74-77. DOI: 10.1016/j.foodchem.2009.04.089

9. Furletti, VF. Ação de extratos, óleos essenciais e frações isoladas de plantas medicinais sobre a formação do biofilme em espécies da levedura Candida spp. [tese]. Piracicaba: Universidade Estadual de Campinas; 2009.

10. Odds FC, Bernaerts R. CHROMagar Candida, a new differential isolation medium for presuntive identification of clinically important Candida species. J Clin Microbiol. 1994; 32 (8): 19239. Disponível em: <http://www.ncbi.nlm.nih.gov/pmc/articles/ PMC263904/pdf/jcm00008-0101.pdf>

11. Bankova V. Chemical diversity of propolis and the problem of standardization. J Ethnopharmacol. 2005; 100 (1-2): 114-7. DOI: 10.1016/j.jep.2005.05.004

12. Silva BB. Caracterização da própolis vermelha: sua origem botânica e o efeito sazonal sobre sua composição química e atividade biológica [dissertação]. Piracicaba: Universidade Estadual de Campinas; 2008.

13. Alencar SM, Oldoni TLC, Castro ML, Cabral ISR, Costa-Neto CM, Cury JÁ, et al. Chemical composition and biological activity of a new type of Brazilian propolis: Red propolis. J. Ethnopharmacol. 2007; 113 (2): 278- 83. DOI: 10.1016/j.jep.2007.06.005

14. Pfaller MA, Huston A, Coffman S. Application of CHROMagar Candida Medium for rapid screening of clinical specimens for Candida albicans, Candida tropicalis, Candida krusei and Candida (Torulopsis) glabrata. J Clin Microbiol. 1996 Jan;34(1): 58-61. PubMed PMID: 8748273; PubMed Central PMCID: PMC228730.

15. Beighton D, Ludford R, Clark DT, Brailsford SR, Pankhurst CL, Tinsley GF, et al. Use of CHROMagar Candida Medium for isolation of yeasts from dental samples. J Clin Microbiol. 1995; 33(11): 3025-7. PubMed PMID: 8576366; PubMed Central PMCID: PMC228627.

16. Duarte S, Koo H, Bowen WH, Hayacibara MF, Cury JA, Ikegaki $M$, et al. Effect of a novel type of propolis and it is cheminical factions on glucosy transferases and on growth and aderece of mutans streptococci. Biol Pharm Bull. 2003; 26(4): 527-31. DOI: $10.1248 / \mathrm{bpb} .26 .527$

17. Erkose G, Erturan Z. Oral Candida colonization of human immunodeficiency virus infected subjects in Turkey and its relation with viral load and CD4+ T- lymphocyte count. Mycoses. 2007: 50 (6): 485-90. DOI: 10.1111/j.1439-0507.2007.01393.x
18. Oksuz S, Sahin I, Yildirim M, Gulcan A, Yavuz T, Kaya D, et al. Phospholipase and proteinase activities in diferente Candida species isolated from anatomically distinct sites of healthy adults. Jpn J Infect Dis. 2007 Sep; 60(5): 280-3. PubMed PMID: 17881867

19. Ribeiro EL, Campos C, Crespo AM, Castro JS, Rocha FP, Alves $M$, et al. Detection of phospholipidolytic Candida albicans isolated from saliva of children with Down's syndrome. Acta Med Port. 2002 May-Jun; 15(3): 171-4. PubMed PMID: 12379993. Disponível em: <http://www.actamedicaportuguesa. com/revista/index.php/amp/article/view/1931/1499>

20. Rupp S. Interactions of the fungal pathogen Candida albicans with the host. Future Microbiol. 2007 Apr; 2(2): 141-51. DOI: 10.2217/17460913.2.2.141

21. White SJ, Rosenbach $A$, Lephart $P$, Nguyen $D$, Benjamin $A$, Tzipori S, et al. Self-Regulation of Candida albicans population size during GI colonization. PLoS Pathog. 2007 Dec; 3 (12): 184. DOI: 10.1371/journal.ppat.0030184

22. Ibrahim AS, Mirbod F, Filler SG, Banno Y, Cole GT, Kitajima Y, et al. Evidence implicating phospholipase as a virulence factor of Candida albicans. Infect Immun. 1995 May; 63(5): 1993-8. PubMed PMID: 7729913; PubMed Central PMCID: PMC173255.

23. Azevedo RVP, Komesu MC, Candido RC, Salvetti C, Rezende, FHC. Candida sp. in the oral cavity with and without lesions: maximal inhibitory dilution of Propolis and Periogard. Rev Microbiol. 1999; 30 (4): 335-41.DOI: 10.1590/S000137141999000400008

24. Silva CRG, Melo KE, Leão MVP, Ruis R, Jorge AOC. Presença de Candida nas mucosas vaginal e oral e sua relação com lgA salivar. Rev Bras Ginecol Obstet. 2008 Jun; 30 (6): 300-5. DOI: 10.1590/S0100-72032008000600006

25. Spolidorio LC, Martins VRG, Nogueira RD, Spolidorio DMP. Frequência de Candida sp. em biópsias de lesões da mucosa bucal. Pesqui odontol bras. 2003; 17 (1): 89-93. DOI: 10.1590/ S1517-74912003000100017

26. Samaranayake YH, Samaranayake LP. Experimental oral candidiasis in animal models. Clin Microbiol Rev. 2001 Apr; 14 (2): 398-429. DOI: 10.1128/CMR.14.2.398-429.2001

27. Figueiredo MC, Marset VM, Kuroczka WF, Silva KVCL. Diagnosing and raising awareness about oral and cervicovaginal diseases. Stomatos. 2012; 18 (34): 16-28. [Acesso em: 13 Maio 2015]. Disponível em: http://www.periodicos.ulbra.br/index. php/Stomatos/article/view/502/337

28. Neville BW, Damm DD, Allen CM, Bouquot JE. Patologia oral e maxilofacial. 3. ed. Rio de Janeiro: Elsevier; 2009.

29. Sawaya ACHF, Palma AM, Caetano FM, Marcucci MC, Da Silva Cunha IB, Araujo CEP, et al. Comparative study of in vitro methods used to analyse the activity of propolis extracts with different compositions against species of Candida. Lett Appl Microbiol. 2002; 35 (3): 203-7. DOI: 10.1046/j.1472-765X.2002.01169.x 
30. Uzel A, Sorkun K, Onçag O, Çogulu D, Gençay O, Salih B. Chemical compositions and antimicrobial activities of four different Anatolian propolis samples. Microbiol. res. 2005; 160 : 189-95. DOI: 10.1016/j.micres.2005.01.002

31. Sforcin JM, Fernandes Júnior A, Lopes CAM, Funari SRC, Bankova V. Seasonal effect of Brazilian propolis on Candida albicans and Candida tropicalis. J. venom. anim. toxins. 2001; 7 (1): 139-44. DOI: 10.1590/S0104-79302001000100009

32. Oliveira ACP, Shinobu CS, Longhini R, Franco SL, Svidzinski TIE. Antifungal activity of propolis extract against yeasts isolated from onychomycosis lesions. Mem Inst Oswaldo Cruz. 2006; 101 (5): 493-7. DOI: 10.1590/S0074-02762006000500002

33. Portilho DR, Melo IA, Guerra RC, Batista $H L$, Fernandes $C H C$. Avaliação da atividade antibacteriana e antifúngica da própolis produzida no estado do Tocantins. Rev Cient ITPAC. 2013; 6 (2): 1-8. [Acesso em: 15 maio 2015]. Disponível em: <http:// webcache.googleusercontent.com/search?q=cache:http:// www.itpac.br/arquivos/Revista/62/1.pdf>

34. Fernandes Júnior $A$, Lopes MMR, Colombari V, Monteiro ACM, Vieira EP. Atividade antimicrobiana de propolis de Apis mellifera obtidas em três regiões do Brasil. Cienc Rural. 2006; 36 (1): 294 7. DOI: $10.1590 /$ S0103-84782006000100047

35. Kujumgiev A, Tsvetkova I, Serkedjieva Y, Bankova V, Christov R, Popov S. Antibacterial, antifungal and antiviral activity of propolis of different geographic origin. J Ethnopharmacol. 1999; 64: 235-240. DOI: 10.1016/S0378-8741(98)00131-7

36. Drago L, Mombelli B, De Vechi E, Fassina MC, Tocalli L, Gismondo MR. In Vitro antimicrobial activity of propolis dry extract. J Chemother. 2000; 12(5): 390-5. DOI: 10.1179/ joc.2000.12.5.390

37. Molina FP, Majewski M, Perrela FA, Oliveira LD, Junqueira JC, Jorge AOC. Própolis, sálvia, calêndula e mamona-atividade antifúngica de extratos naturais sobre cepas de Candida albicans. Cienc Odontol Bras. 2008 abr./jun.; 11 (2): 86-93. DOI: 10.14295/bds.2008.v11i2.472

38. Ota C, Unterkircher C, Fantinato V, Shimizu MT. Antifungal activity of propolis on different species of Candida. Mycoses. 2001 Nov; 44(9-10): 375-8. DOI: 10.1046/j.1439-0507.2001.00671.x

39. Silva RA, Rodrigues AE, Ribeiro MCM, Custódio AR, Andrade NED, Pereira WE. Características físico-químicas e atividade antimicrobiana de extratos de própolis da Paraíba, Brasil. Cienc Rural. 2006; 36 (6): 1842-8. DOI: 10.1590/S010384782006000600027

40. Ikegaki M. Determinação da qualidade de própolis de Apis mellifera africanizada da região sul do Brasil: avaliação de algumas propriedades físico-químicas e biológicas da própolis [tese]. São Paulo: Curso de Pós-graduação em Ciência de Alimentos, Faculdade Engenharia de Alimentos, Universidade de Campinas, UNICAMP; 2001

41. Bispo Junior W, Miranda EO, Alvino V, Araujo B, Silva DW, Porfirio Z. Atividade antimicrobiana de frações da própolis vermelha de Alagoas, Brasil. Semin Cienc Biol Saude. 2012; 33 (1): 03-10. DOI: 10.5433/1679-0367.2012v33n1p03
42. Oliveira KAM, Oliveira GV, Batalini C, Rosalem JA, Ribeiro LS. Atividade antimicrobiana e quantificação de Flavonoides e Fenóis totais em diferentes extratos de Própolis. Semin Cienc Biol Saude. 2012; 33 (2): 211-22. DOI: 10.5433/1679-0367.2012v33n2p211

43. Pinto MS, Faria JE, Message D, Cassini STA, Pereira CS, Giosso MM. Efeito de extrato de própolis verde sobre bactérias patogênicas isoladas do leite de vacas com mastite. Braz $j$ vet res anim sci. 2001; 38 (6): 278-83. DOI: 10.1590/S141395962001000600006

44. Vargas AC, Loguercio AP, Witt NM, Costa MM, Silva MS, Viana LR. Atividade antimicrobiana "in vitro" de extrato alcoólico de propolis. Cienc Rural. 2004; 34: 159-163. DOI: 10.1590/S010384782004000100024

\section{Comment on this article:}

\section{(f) $[$ in $8+\mathbf{S} P$}

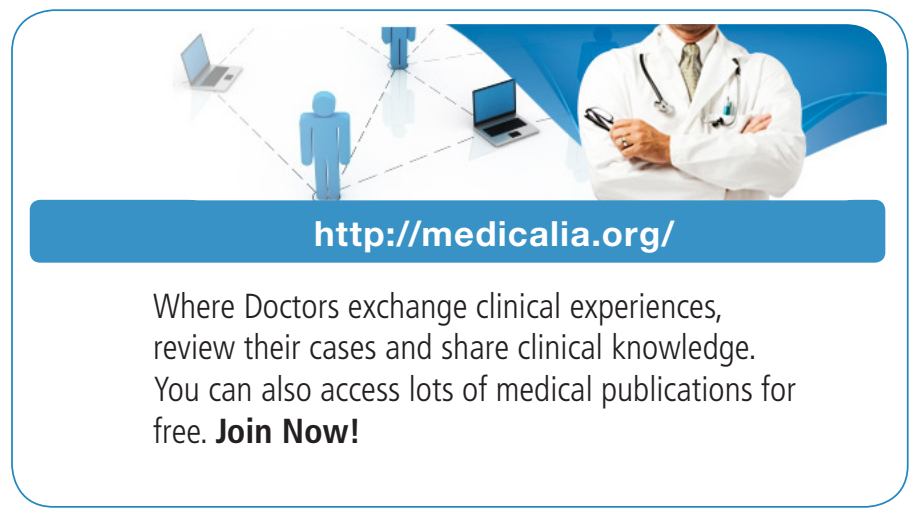

Publish with iMedPub

\section{http://www.imed.pub}

International Archives of Medicine is an open access journal publishing articles encompassing all aspects of medical science and clinical practice. IAM is considered a megajournal with independent sections on all areas of medicine. IAM is a really international journal with authors and board members from all around the world. The journal is widely indexed and classified Q1 in category Medicine. 